\title{
Hyperglycaemic Hyperosmolar Non-Ketotic Coma in a Non-diabetic Child
}

Dear Sir,

In a recent review article [1], Bratusch-Marrain pointed out that adrenaline is the most potent diabetogenic hormone. We wish to report our experience with a non-diabetic child who survived an episode of hyperglycaemic non-ketotic coma following adrenaline treatment for asthma.

A 10-year-old girl had symptoms of an upper respiratory infection for 2 days prior to being seen in the clinic. On examination she was pyrexial $\left(37.8^{\circ} \mathrm{C}\right)$ and wheezing. An SC injection of $0.2 \mathrm{ml}$ of $1: 1,000$ aqueous adrenaline was given. Twenty minutes later, $0.1 \mathrm{ml}$ of $1: 1,000$ aqueous adrenaline was administered. Ten minutes after the second injection, she developed a sense of urgency, became incontinent and confused. Twenty minutes later, she continued to wheeze, and an IV infusion of $250 \mathrm{mg}$ of aminophylline in $500 \mathrm{ml}$ of $5 \%$ glucose and $0.45 \%$ saline was started. Within 5-10 min, and after $50 \mathrm{ml}$ of the solution had been infused, she had a generalized convulsion. She had no history of abdominal pain, convulsions, polyuria, or weight loss and no history of trauma, drug ingestion, or unusual diet. Her family history was unremarkable.

Examination at the referral hospital showed a comatose girl with shallow, but spontaneous respirations. The axillary temperature was $37.3^{\circ} \mathrm{C}$; pulse 120 beats $/ \mathrm{min}$ and blood pressure $90 / 60 \mathrm{mmHg}$. Her height was $130 \mathrm{~cm}$ and weight $26 \mathrm{~kg}$, with no evidence of dehydration. The pupils were symmetrical, $8 \mathrm{~mm}$ in diameter, and sluggishly reactive to light. Deep tendon reflexes were symmetrically diminished. The remainder of the examination was unremarkable other than minimal rhonchi.

Laboratory values obtained $30-40 \mathrm{~min}$ after the first seizure and prior to starting further IV fluids were: normal haemoglobin and white blood count; serum urea $0.18 \mathrm{mmol} / 1$; serum $\mathrm{Na}^{+} 128 \mathrm{mmol} / 1$; $\mathrm{K}^{+} 3.9 \mathrm{mmol} / 1 ; \mathrm{Cl}^{-} 90 \mathrm{mmol} / 1 ; \mathrm{HCO}_{3}^{-} 20 \mathrm{mmol} / \mathrm{l}$; and serum $\mathrm{pH}$ 7.32. Blood glucose was $71 \mathrm{mmol} / \mathrm{l}$; serum ketones were negative; and serum osmolarity was $350 \mathrm{mOsm} / 1$; urinalysis showed $5 \%$ glucose with negative ketones and protein. Plasma insulin level was $12 \mathrm{mU} / \mathrm{l}$; serum theophylline $<1.0 \mu \mathrm{g} / \mathrm{ml}$; salicylate level 0.41 $\mathrm{mmol} / \mathrm{l}$; serum amylase was $60 \mathrm{IU} / \mathrm{l}$ (normal 50-200); and AST was $18 \mathrm{mU} / \mathrm{l}$. A toxicology screen was negative. Cerebral spinal fluid contained glucose $6.7 \mathrm{mmol} / 1$, protein $11 \mathrm{mg} / \mathrm{dl}$, and was negative for $\mathrm{cy}$ tology and culture. An EEG revealed diffuse disturbance of cerebral function, but without focal features or seizure patterns; a CT brain scan was normal.

A chest X-ray showed slightly hyper-expanded lungs. Urinary noradrenaline and adrenaline were $28 \mu \mathrm{g}$ and $13 \mu \mathrm{g} / 24 \mathrm{~h}$, respectively; serum thyroxine was $123 \mathrm{nmol} / 1$.

Recurrent seizure activity required general anaesthesia. Her hyperglycaemia responded to IV fluid and 3 units of SC crystalline insulin. She had a blood glucose of $11.4 \mathrm{mmol} / \mathrm{l}$ at $12 \mathrm{~h}$. However, she remained comatose for $96 \mathrm{~h}$ and regained consciousness on the fifth hospital day. She then experienced difficulty in both receptive and expressive language, and had brief, transient episodes of confusion. Ten days after admission, her mental state returned to normal, although there was some decrease in fine motor coordination. Four-hour urine fractionals from day 2 in hospital until discharge on day 12 revealed no glycosuria. Fasting and $2 \mathrm{~h}$ post-prandial blood glucoses, 7 days after admission, were 3.9 and $5.5 \mathrm{mmol} / 1$, with plasma insulin values of 15 and $60 \mathrm{mU} / 1$, respectively. The child was discharged without insulin therapy. On follow-up, at ages 13 and 16 years, the child was in good health, and glucose, C-peptide, insulin and glucagon responses to glucose and arginine tolerance tests were normal.
We have no definite explanation for this potentially catastrophic event [2]. However, adrenaline's effect on pancreatic A and B cell function is well known, with suppression of insulin release and stimulation of glucagon via the $\alpha$ and $\beta$ adrenergic systems. Although we have no proof of hyperglucagonaemia, the inappropriately low serum insulin was involved in producing the hyperosmolar state. Subsequent glucose and arginine tolerance tests gave no indication of pancreatic A or B cell dysfunction. Nevertheless, a latent defect in B, and possibly $A$ cell function secondary to an adrenergic imbalance could be postulated. Adrenergic influence on basal and stimulated insulin secretion has been well documented in man, and precedence for the clinical relevance of adrenergic imbalance are reports by Robertson et al. [3] and Podolsky and Pattavina [4]. It is important to note that our patient had a rapid onset as opposed to the more usual insidious development [5]. The facts that symptoms occurred before the administration of aminophylline, that the quantity of aminophylline received was limited and that aminophylline does not alter blood glucose levels in man [6], suggest that aminophylline toxicity did not play a role in this child's hyperosmolar state or seizure activity [7].

This case extends the suggestion of a previous report [4] that an adrenergic imbalance plays a role in some cases of hyperglycaemic hyperosmolar non-ketotic coma, that the diabetogenic effect of adrenaline may be significantly enhanced in certain individuals with adrenergic imbalance, and that severe impairment of carbohydrate metabolism can occur in a child without evidence of residual glucose intolerance.

Yours sincerely,

W. H. Hoffman and S.S. Fernados

\section{References}

1. Bratusch-Marrain PR (1983) Insulin-counteracting hormones: their impact on glucose metabolism. Diabetologia 24: 74-79

2. Mather HM (1980) Management of hyperosmolar coma. J Roy Soc Med 73: 134-137

3. Robertson RP, Hazzard WR, Brunzell JD, Lerner RL, Porte D (1972) Paradoxical hypoglycaemia: An alpha-adrenergic-mediated response to glucose. Lancet 2: 787-789

4. Pololsky S, Pattavina CG (1973) Hyperosmolar non-ketotic diabetic coma: A complication of propranolol therapy. Metabolism 22: 685-693

5. Gerich JE, Martin MM, Recant L (1971) Clinical and metabolic characteristics of hyperosmolar nonketotic coma. Diabetes 20: 228-237

6. Ensinck JW, Stoll RW, Gale CC, Santen RJ, Touber JL, Williams RH (1970) Effect of aminophylline on the secretion of insulin, glucagon, luteinizing hormone, and growth hormone in humans. $J$ Clin Endocrinol Metab 31: 153-161

7. Gaudreault P, Wason S, Lovejoy FH (1983) Acute pediatric theophylline overdose: a summary of 28 cases. J Pediatr 102: 474-476

Dr. William H. Hoffman

Pediatric Endocrinology

Children's Hospital of Michigan

Detroit, Michigan 48201

USA 